\title{
Impact-Investing in The Healthcare in Terms of the New Socially Responsible State Investment Policy
}

\author{
http://doi.org/10.21272/bel.4(3).57-64.2020
}

Julia Yelnikova, ORCID: https://orcid.org/0000-0002-8478-4716

$\mathrm{PhD}$ in Economics, Senior Scientific Researcher, Sumy State University, Sumy, Ukraine

\author{
Aleksy Kwilinski, ORCID: https://orcid.org/0000-0001-6318-4001 \\ $\mathrm{PhD}$ in Economics, The London Academy of Science and Business, London, UK
}

\begin{abstract}
The article reveals the issue regarding the implementation of impact-investing in the health care system and its comparison with other traditional investment mechanisms. The relevance of the study is to show the destructive impact of the COVID-19 pandemic on investment processes. According to the WHO and the UN, the global pandemic, unpreparedness of the Ukrainian health care system, and the lack of progress in achieving the Sustainable Development Goal 3 calls into question the conclusions of the Voluntary National Review "Sustainable Development Goals Ukraine 2020". The investment instruments against COVID-19 in 2020 are conceptualized. The private companies' assistance in this fight is studied. The study defines that most assistance is charitable rather than investing. Given the systematic and integrated practices of socially responsible business support for the health sector in SER companies' strategy or the implementation of publicprivate partnerships in this area, such support could be transformed into mutually beneficial investment projects and after overcoming the pandemic impact. The authors prove that impact-investing is a useful tool for building and restoring the economy through a new socially responsible state investment policy. The current state of public investment project implementation in the health care field is assessed. According to the results, it is necessary to improve transparency, investment monitoring of projects and executive discipline in their implementation. Lack of generally accepted standards of transparency, measurement and impact management, along with an unformed system of benchmarks minimizing reputational risks and reducing transaction costs in the market of impact-investing and responsible investment in general (considering data from surveys of the Global Network on impact-investing) are fundamental limitations which hinder its development, in particular in Ukraine. Recommendations are given to develop the impact-investing in the context of new public investment policy to overcome these limitations, regarding the best practices in promoting the impact-investing policy.
\end{abstract}

Keywords: Impact-investing, Investment Policy, Investors, Sustainable Development Goals, Social Responsibility, State Investment Policy.

JEL Classification: D25, E22, M14, O10, Q01.

This work is licensed under a Creative Commons Attribution 4.0 International License

Cite as: Yelnikova, J., Kwilinski, A. (2020). Impact-Investing in The Healthcare in Terms of the New Socially Responsible State Investment Policy. Business Ethics and Leadership, 4(3), 57-64. http://doi.org/10.21272/bel.4(3).57-64.2020.

(C) The Authors, 2020. This article is published with open access at Sumy State University.

\section{Introduction}

In modern conditions of a well-developed national economy, one can observe the growing role of investment in various fields of state processes. The number of public funds cannot provide sufficient and full financing of all sustainable development spheres. The introduction of innovations and reforms requires additional funds and their rational application. That is why there is a need to find new methods and mechanisms for attracting foreign capital into the national development system. Among these ways, there is an impact-investing in terms of a new socially responsible public investment policy. This area must be greatly provided by investment, and the global risks of pandemic need to be significantly leveled due to the growing health challenges caused by the COVID-19 pandemic in 2019-2020. Influential investments and a particular sustainable investment can become its source. Among the 17 SDG of the UNO in terms of the global health crisis, the SDG 3 "Ensuring a Healthy Lifestyle and Promoting Well-Being for All at All Ages" and its target 3.8, Task 3d and especially 
Task 3c "Significantly to increase health care funding and the recruitment, development, training and maintenance of health personnel in developing countries" are worth noticing. The World Health Organization estimates that the investment gap in the world in achieving the goals and objectives of SDG 3 (Ensuring Healthy Living and Promoting Well-Being for Everyone) is $\$ 54$ billion annually by 2030. In terms of the COVID-19 pandemic and the necessity to modernize the health care infrastructure, especially in developing countries, the amount of investment gap is increasing. In Ukraine, the risks of a pandemic are multiplied within the framework of chronic underfunding of this sector and incomplete medical reform.

\section{Literature Review}

The foreign and domestic scientists consider the issue of the investment policy state regulation and practical steps to its modernization, in their works. Key aspects of impact investment development were investigated by Abt W. (2018), Barton D. (2017), Davies G. B. (2015), Johnson K., Lee H. (2013), French Sh. (2107), Niculescu M. (2017), Payiatakis D., Brooks P. (2018). Yatsenko A. (2010) revealed the feasibility of introducing the innovative elements in the modern system of investment policy and described the theoretical aspects for state regulation of investment activities. Particular attention should be paid to such authors as Wood D., Thornley B., Grace K., Sullivant S. In their work "Impact-Investing: A Framework for Policy Design and Analysis" (Wood D., Thornley B., Grace K., Sullivant S., 2011) they emphasize that the state has a crucial role in stimulating the development of impact-investing, in levelling restrictions and information asymmetry in the market, promoting positive externalities in the practice of investors, especially in the current crisis. However, the impact of the current situation in the health care field and its investment in terms of the coronavirus crisis is not reflected in the analyzed works.

\section{Results}

Impact-investing, as one of the responsible investment instruments (RI) has a leading role in eliminating market failures and the state in the investment provision of social services. This relatively new type of investment in the financial market and within the state investment policy (SIP) caused many restrictions in its extension. Thus, the Global Impact Investment Network (GIIN 2020 Annual impact investment survey) identified key challenges and restrictions in the development of this investment. There were 294 leading organizations in the field of impact-investing among the respondents. The survey provided a multiple-choice (Fig. 1).

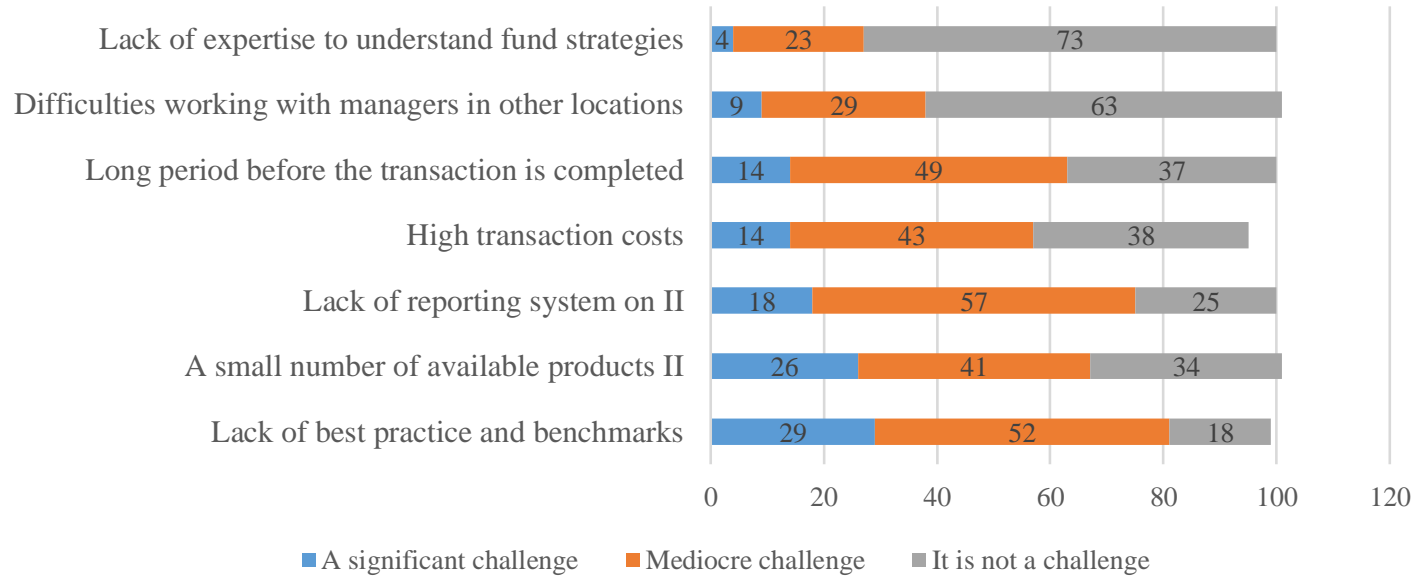

Figure 1. The largest challenges in impact-investing according to asset managers, 2020, \%

Source: GIIN (2020) Annual impact investment survey

Thus, the key challenges include the lack of reputational information about companies, the small number of impact-investing products on the market, and the low level of reporting on impact-investing (29, 26 and 18\% of respondents). More than half of the respondents relate the reputational and transparency risks to ordinary challenges (52 and 57\%). The concretization of these challenges in the impact-investing development in comparison with traditional investment mechanisms lies in the plane of measuring and controlling the investment impact (Fig. 2). 


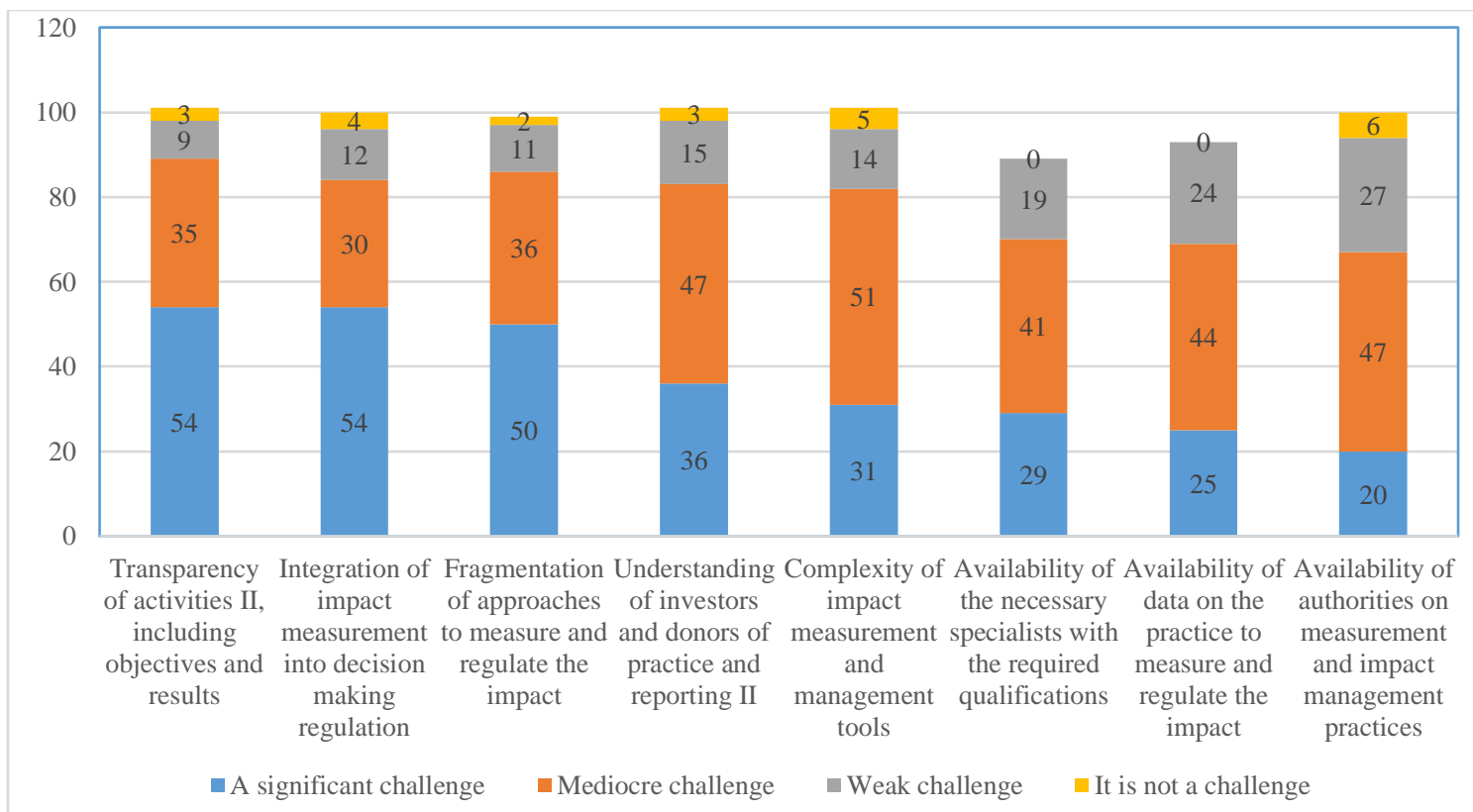

Figure 2. The significance degree of challenges in measuring and controlling the influence of impact-investing, 2019, \% Source: GIIN (2020)

Thus, we should note that among the 278 surveyed impact investors from various countries in percentage terms, it is possible to identify two respondents. The first group considers the most significant challenges to ensure the transparency of impact investors, including goals and results, the integration of impact measurement into decision management (54\% of respondents), and fragment approaches to measuring and controlling the impact. The second group considers the rest of the challenges to be an ordinary impact.

In our opinion, the lack of generally accepted standards of transparency, measurement, and regulation of impact, along with the unformed system of benchmarks that minimize reputational risks and reduce transaction costs in the impact-investing market and responsible investing in general, are main restrictions to its development. SIP is the lever of regulatory influence of the state on investment processes. This policy must eliminate these restrictions by developing a model of RI as a mechanism for implementing SIP, by the use of impact-investing and combining positive social or environmental impact that is inherent to the public investment projects, with financial efficiency. Some challenges in terms of forming a new SIP in Ukraine are the following:

$>$ the necessity to stimulate impact-investing in low-return sectors, mainly to fight the climate change, to invest the depressed regions (including the ATO zone) in conditions of insufficient investment activity of the state and state enterprises;

$>$ preferences for large companies in comparison with the small social enterprises in access to public investment resources and participation in public-private partnership projects for the implementation of infrastructure projects, health projects, strengthening food security;

$>$ the low level of investors' awareness about new investment strategies in the conditions of insufficient development not only of BI market but also of the financial market in general, low level of companies' social responsibility as providers of positive influence and low level of investment culture and financial literacy of the population as a source for savings and resources.

Despite the diversity of indicators for measuring social and environmental impact within impact-investing, investors developed many priority areas for their implementation (Fig. 3) 


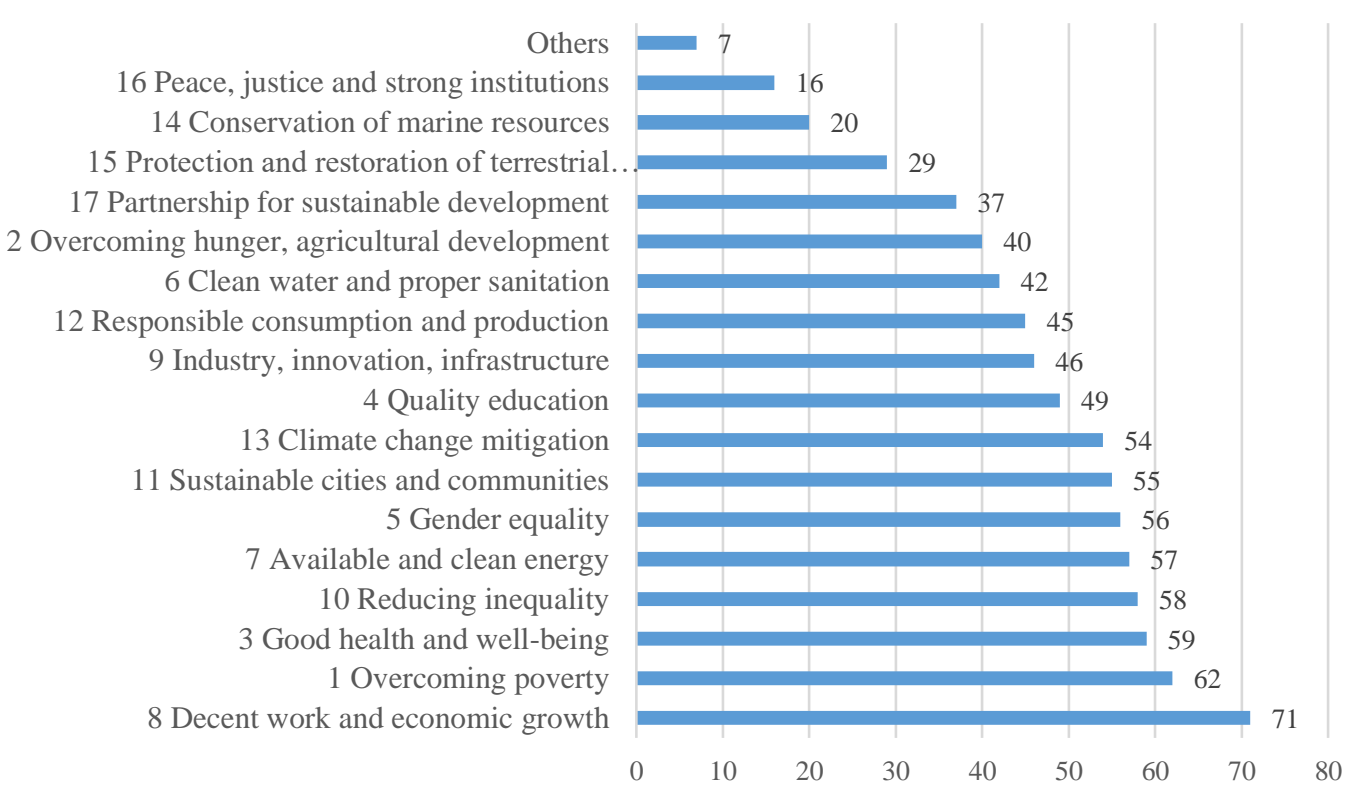

Figure 3. Priority SDGs targeted by impact-investors in $2020, \%$ of respondents

Source: GIIN (2020) Annual Impact Investor Survey

As we can see, the most relevant SDGs for the implementation of RI and the most relevant SDGs for the implementation of impact investments, the top three goals include the SDG 3 Strong health and well-being. Among the 294 surveyed impact-investors, 59\% consider investing in projects related to the progress towards this goal to be one of their priorities. Analyzing the experience of Ukraine in the context of RI, health care investment on the way to SDG, including through SIP, and taking into account the challenges of the global pandemic and economic recession, we should focus on the following aspects of the analysis:

Level of achievement of SDG 3 in Ukraine.

Investment response to COVID-19 challenges.

The state investment support in the field of health care.

Thus, the following factors should be noted regarding the level of achievement of SDG 3 and its national objectives in Ukraine. According to the WHO and the UN, the global pandemic and the unreadiness of the Ukrainian health care system, along with the insufficient achievement of SDG 3, calls into question the conclusions of the Voluntary National Review "Sustainable Development Goals of Ukraine", published in summer of 2020. According to these conclusions, SDG 3 relates to the goals achieved by the integral criterion (the achievement level is about $80 \%$ ) or has a high probability of being achieved. Among fifteen indicators of national goals for achieving the SDG 3, nine signs have weak positive or negative dynamics (Voluntary National Review "Sustainable Development Goals of Ukraine"). Some of them are given in Table. 1.

Table 1. National tasks of SDG 3, which require an increase in investment to achieve the target on the horizon by 2030

\begin{tabular}{|c|c|c|c|c|c|c|c|c|c|}
\hline Task & Indicator & 2015 & 2016 & 2017 & 2018 & 2019 & 2020 & 2025 & 2030 \\
\hline \multicolumn{10}{|c|}{ The dynamics are positive but require significant acceleration to reach the target } \\
\hline \multirow[t]{2}{*}{$\begin{array}{l}\text { 3.4 To reduce premature } \\
\text { mortality from non- } \\
\text { communicable diseases }\end{array}$} & $\begin{array}{l}\text { The number of deaths of } \\
\text { men from cerebrovascular } \\
\text { diseases aged } 30-59 \text { years } \\
\text { per } 100 \text { thousand men of } \\
\text { the corresponding age }\end{array}$ & 64,0 & 63,0 & 62,3 & 62,1 & - & 52,6 & 52,0 & 50,0 \\
\hline & $\begin{array}{l}\text { The number of deaths of } \\
\text { women from malignant } \\
\text { neoplasms of the cervix } \\
\text { aged } 30-59 \text { years per } 100 \\
\text { thousand women of the } \\
\text { appropriate age }\end{array}$ & 12,2 & 12,8 & 12,0 & 11,5 & - & 11,0 & 11-10 & $10-9$ \\
\hline $\begin{array}{l}3.8 \text { To reduce smoking } \\
\text { among the population } \\
\text { using innovative means } \\
\text { of informing about the } \\
\text { negative consequences }\end{array}$ & $\begin{array}{l}3.8 .2 \text { The share of } \\
\text { smokers among 16-29- } \\
\text { years old men, \% }\end{array}$ & 31,4 & 34,4 & 28,9 & 27,9 & 29,3 & 27,0 & 23,0 & 20,0 \\
\hline
\end{tabular}


Table 1 (cont.). National tasks of SDG 3, which require an increase in investment to achieve the target on the horizon by 2030

\begin{tabular}{|c|c|c|c|c|c|c|c|c|c|}
\hline $\begin{array}{l}3.3 \text { To stop the } \\
\text { epidemic of HIV / AIDS } \\
\text { and tuberculosis }\end{array}$ & $\begin{array}{l}\text { 3.3.1 Number of patients } \\
\text { firstly diagnosed with } \\
\text { HIV per 100,000 } \\
\text { population }\end{array}$ & 37,0 & 40,0 & 42,8 & 42,8 & - & 30,9 & 24,8 & 20,6 \\
\hline $\begin{array}{l}3.8 \text { To reduce the } \\
\text { smoking among the } \\
\text { population using } \\
\text { innovative means of } \\
\text { informing about the } \\
\text { negative consequences }\end{array}$ & $\begin{array}{l}3.8 .1 \text { The share of } \\
\text { smokers among 16-29- } \\
\text { years old women, \% }\end{array}$ & 5,0 & 5,1 & 5,2 & 4,8 & 7,5 & 4,5 & 4,0 & 4,0 \\
\hline $\begin{array}{l}\text { 3.9 To reform health } \\
\text { care financing }\end{array}$ & $\begin{array}{l}3.9 .1 \text { The share of } \\
\text { citizens' expenditures in } \\
\text { total health expenditures, } \\
\%\end{array}$ & 48,78 & 52,29 & 47,45 & 48,24 & - & 40,00 & 35,00 & 30,00 \\
\hline
\end{tabular}

Source: Compiled by the author according to (Voluntary National Review "Sustainable Development Goals of Ukraine")

Other national tasks of SDG 3 that require significant acceleration include task 3.6 (3.6.2 Number of injured persons due to road accidents per 100 thousand population (by mode of transport) and 3.7.1 Level of population immunization according to the Calendar of preventive vaccinations to certain six age groups at prevention of infectious diseases (by type of disease). However, the essential task concerning the latter is to reform health care financing. According to the report (Voluntary National Review "Sustainable Development Goals of Ukraine"): "budget expenditures mainly consisted of health care expenditures on salaries and utilities (about 75\%). In such circumstances, there are very few financial opportunities for the actual provision of services, i.e., treatment of patients, purchase of medicines and consumables, renewal of technological funds. Stable funding and increased health expenditures are necessary to expand further the number of free services guaranteed by the state and improve the material and technical base of hospitals..." .

One should note the following facts regarding the response to COVID-19 health challenges, multiplied by the necessity to provide current medical services in the absence of funding and the need for technical re-equipment of medical institutions. The private donor funds compensated systemic underfunding and lack of public investment resources in this area during Ukraine's independence during the pandemic. The generalization of more than 300 national practices to counteract COVID-19 by the expert organization "SDG Development Center" made it possible to define the scale of the following financial support: UAH 1,549,157,070, by which 1.4 million personal protective equipment, 360 artificial lung ventilation, and 75 other devices and diagnostic systems were purchased, 72,709 rapid tests and 37,290 litres of disinfectant, 272 hospitals and ambulance stations were given assistance. However, one should note that the outlined support in the current situation is like the charitable assistance. Given the systematic and integrated practices of socially responsible business support for the health care sector in the strategy of CSR companies or the implementation of public-private partnerships in this area, such support could be transformed into mutually beneficial investment projects and become impact-investing after overcoming the pandemic impact.

In contrast to the significance of the private companies' contribution to the financing of measures to fight COVID-19, significant inefficiency evidence of public investment projects in health care financed under the current SIP model should include the delay in funding, its incompleteness, delay in implementation of these projects, ineffective use of provided investment resources. As a result, we observe a low readiness of the healthcare sector to counteract COVID-19, short supply of benefits and advantages for medical services consumers and irrational use of investment resources. The analysis of the state investment projects implementation for 2019 as of 01.01.2020 conducted according to the minutes of the meeting of the interdepartmental commission on state investment projects forms the basis for the above conclusions (Table 2).

Table 2. Sampling of funds in the implementation of public investment projects in Ukraine in 2016-2019

\begin{tabular}{|c|c|c|c|}
\hline Year & Sample of funds, \% & $\begin{array}{c}\text { Planned volume of investments, } \\
\text { UAH million }\end{array}$ & Real amount of funding, UAH \\
\hline 2016 & 75,0 & 1000,00 & 748,00 \\
\hline 2017 & 82,0 & 1850,00 & 1564,00 \\
\hline 2018 & 96,3 & 1824,60 & 1756,70 \\
\hline 2019 & 91,0 & 2539,43 & 2249,84 \\
\hline
\end{tabular}

Source: Based on the Minutes of the meeting of the interdepartmental commission on state investment projects dated 25.05.2020 
Despite the growing sample size observed during the analyzed period, such indicators are averaged and describe only those projects that were evaluated by the commission. According to many budgetary units, public investment projects were not assessed, including in the field of health care. Eleven public investment projects funded in 2019 by total managers such as the Ministry of Health, the National Academy of Medical Sciences of Ukraine and the State Administration of Project Evaluation are distributed in the following way:

$>$ only three projects are $100 \%$ effective and are evaluated as "satisfactory";

$>$ two projects are 19\% and 38\% effective, evaluated as "partially satisfactory";

$>$ two projects were not performed in 2019 and are evaluated as "unsatisfactory";

$>$ four projects have not been evaluated at all.

However, suppose we apply the "traffic lights" methodology to evaluate the public investment projects, which was tested by the monitoring report of the Ministry of Economic Development and Trade in 2016 (Monitoring of Public Investment Projects for 2016) to these projects. In addition to three unsatisfactory projects, the other eight projects are in the yellow-red category (deviation of the actual from the planned investment costs is 30\%-50\%) and in the red category (difference exceeds 50\%). The reasons for the lack of evaluations for projects or their partial and unsatisfactory implementation are the lack of work on the project in the current year, the redistribution of funds by the interdepartmental commission to other projects, absence of contracts with contractors. One should note that the necessity to respond to the challenges of the COVID-19 pandemic and the need to fulfil Ukraine's commitments to achieve SDG 3 complicate the improvement of such a negative situation in the public investment projects implementation in health care.

Among the possible areas for its improvement, one should mention the following:

$>$ to reform the health care to reduce the payments for the population for its financing, ensuring its adequacy and transparency;

$>$ to strengthen the effectiveness of current public investment projects in health care;

$>$ to invest in modernization, technical re-equipment of the material and technical base of medical institutions and introduction of modern technologies, including through the public-private partnership mechanism;

$>$ to introduce new tools for health care investing, particularly impact-investing, in the implementation of public investment projects with a clear impact, monitoring and reporting on its achievement by budget managers and the necessary financial efficiency of investments. For private investors - creating additional incentives for such investments in health care.

Let us consider the latter direction in more detail and give more specific recommendations for its implementation in Ukraine. We consider the analysis of the world experience regarding impact-investing to achieve SDG 3 and overcome the coronavirus crisis consequences. The recommendations, developed with the best practices in the design of impact-investing promotion policies, are based on principles. They are universal and implemented as the framework of the SIP, and at the same time, can be specified in the health care, climate change or post-conflict reconstruction. They consider the main six directions of the roadmap for the future development of impact-investing in terms of the new financial system formation (Roadmap for the Future of Impact-Investing). The above recommendations to promote impact-investing through the SIP primarily concern its fundamental principles - the state's influence on supply, demand for investment resources, the formation of the investment chain on a responsible basis, and the elimination of existing restrictions on development. We combine the above in the form of a table (Table 3).

Table 3. Recommendations for the development of impact-investing in Ukraine by means of socially responsible SIP

\begin{tabular}{|l|l|l|}
\hline Interventions of SIP & \multicolumn{1}{|c|}{ Direction } & \multicolumn{1}{c|}{ Measures } \\
\hline $\begin{array}{l}\text { Impact on demand for } \\
\text { investment resources }\end{array}$ & $\begin{array}{l}\text { Formation of the framework } \\
\text { conditions for the implementation } \\
\text { of impact-investing }\end{array}$ & $\begin{array}{l}\text { Design of administration, benchmarks (ratings, rankings, indices) } \\
\text { of RI in general and impact-investing in particular, "rules of the } \\
\text { game" for participants of the new financial system }\end{array}$ \\
\cline { 2 - 4 } & $\begin{array}{l}\text { Identification, standardization and } \\
\text { codification of RI, impact } \\
\text { investment and their products }\end{array}$ & $\begin{array}{l}\text { Development of normative documents to define the essence, } \\
\text { features of the impact-investing strategies development, their key } \\
\text { parameters }\end{array}$ \\
\cline { 2 - 3 } & $\begin{array}{l}\text { Formation of financial literacy and } \\
\text { investment culture of a } \\
\text { responsible investor }\end{array}$ & $\begin{array}{l}\text { Increase of awareness regarding RI products and impact-investing } \\
\text { of professional investors, forming the financial culture of the } \\
\text { population and promoting the formation of a retail investors class, } \\
\text { the transition to behavioral concepts of investment, instead of } \\
\text { traditional, which determine the effectiveness of investment only } \\
\text { in the coordinate system - "risk-return" }\end{array}$ \\
\hline
\end{tabular}


Table 3 (cont.). Recommendations for the development of impact-investing in Ukraine by means of socially responsible SIP

\begin{tabular}{|c|c|c|}
\hline \multirow[t]{3}{*}{$\begin{array}{l}\text { Impact on supply of } \\
\text { investment resources }\end{array}$} & \multirow[t]{2}{*}{$\begin{array}{l}\text { Initiation of impact- investing } \\
\text { projects }\end{array}$} & $\begin{array}{l}\text { Attracting private investors to public-private partnerships in the } \\
\text { most problematic areas that require "effective" investments, but } \\
\text { are not yet interesting for investors: health care, counteraction the } \\
\text { climate change or rebuilding post-conflict areas }\end{array}$ \\
\hline & & $\begin{array}{l}\text { Establishment of the oriented directions and norms of socio- } \\
\text { ecological investment for state-owned enterprises and promoting } \\
\text { the development of their corporate social responsibility }\end{array}$ \\
\hline & $\begin{array}{l}\text { Activation of responsible activity } \\
\text { of "state" institutional investors }\end{array}$ & $\begin{array}{l}\text { Implementation of socio-environmental targets in the pension } \\
\text { fund activities and other social insurance funds while ensuring the } \\
\text { efficiency of their activities and eliminating the resource shortage }\end{array}$ \\
\hline \multirow[t]{5}{*}{$\begin{array}{l}\text { Impact on the } \\
\text { investment resource } \\
\text { motion along the } \\
\text { investment chain }\end{array}$} & \multirow[t]{2}{*}{$\begin{array}{l}\text { Ensuring the transparency of the } \\
\text { RI market and impact- investing }\end{array}$} & $\begin{array}{l}\text { Leveling information asymmetry and moral hazard by means of } \\
\text { influencing the disclosure of information by market participants, } \\
\text { and especially to achieve their declared investment impact, to } \\
\text { promote the structuring of market information and segments } \\
\text { through the development of information intermediaries in the RI } \\
\text { market, to reduce transaction costs }\end{array}$ \\
\hline & & $\begin{array}{l}\text { Establishment of the penal sanctions system for unfair practices } \\
\text { regarding the disclosure of information or impact-investors' } \\
\text { unfair conduct and rewards (industry competitions) for best } \\
\text { management and reporting practices }\end{array}$ \\
\hline & $\begin{array}{l}\text { Extension of best practices to } \\
\text { measure the impact of investments }\end{array}$ & $\begin{array}{l}\text { Instrumental provision of timely and complete management, } \\
\text { monitoring of the effect made by impact-investing and reporting } \\
\text { of impact investors on the achievement of social (in the case of } \\
\text { health care), environmental (in the case of climate change) or } \\
\text { socio-environmental (in the case of post-conflict reconstruction) } \\
\text { areas to stakeholders }\end{array}$ \\
\hline & \multirow[t]{2}{*}{$\begin{array}{l}\text { Impact on the investment chain } \\
\text { parameters }\end{array}$} & $\begin{array}{l}\text { State regulation of the investment resource market by influencing } \\
\text { interest rates, investment resources, risk level, margin, clearing } \\
\text { and other institutions of settlement infrastructure }\end{array}$ \\
\hline & & $\begin{array}{l}\text { Formation of tax and investment incentives (discounts, vacations, } \\
\text { zero-taxation) for impact investment operations }\end{array}$ \\
\hline
\end{tabular}

Source: Compiled by author

\section{Conclusions, Discussion and Recommendations}

Investing in the economy at the current stage of Ukraine's development is an essential process. Innovation policy is observed as a strategy within national innovation systems. An important caveat in the implementation of these recommendations is the need to increase the efficiency of existing investment projects in which the state acts as an investor or partner. Secondly, it is the state's initiation of the first impact investment projects, including via state-private partnership to launch processes in the investment market and to encourage private investors through their own best practices. It is difficult to overestimate the role of the state as a supplier of investment resources, which is specified in the areas, actions of the SIP: according to the Global Network of Impact-Investing, $18 \%$ of assets - sources of capital for impact-investing are controlled by the pension funds.

Recommendations on the introduction of impact-investing as a tool of SIP in the new financial system, specified in the government intervention areas (impact on demand, supply and turnover of investment resources) were further developed. Unlike the existing ones, they are universal. They can be adapted to the most problematic areas in the investment of SDG in Ukraine - health care, fighting climate change, or reconstruction of the post-conflict areas.

Author Contributions. Conceptualization, Julia Yelnikova; data curation, Aleksy Kwilinski; formal analysis, Aleksy Kwilinski; funding acquisition, Julia Yelnikova; investigation, Julia Yelnikova; methodology, Julia Yelnikova; project administration, Aleksy Kwilinski; resources, Julia Yelnikova; software, Julia Yelnikova; supervision, Julia Yelnikova; validation, Julia Yelnikova; visualization, Aleksy Kwilinski; writing - original draft, Aleksy Kwilinski; writing - review \& editing, Julia Yelnikova.

Funding. The material was prepared within the R \& D "Modeling and forecasting of the socio-economic and political roadmap of reforms in Ukraine for the transition to a model of sustainable growth" (applied study, carried out at the expense of the general fund of the state budget, 2018, MES, № 0118U00356). 


\section{Reference}

1. Abt, W. (2018). Almost Everything You Know About Impact-Investing Is Wrong. Stanford Social Innovation Review. Available at: https://ssir.org/articles/entry/almost_everything_you_know_about_impact_investing_is_wrong.

2. Barton, D. (2017). The changing landscape of social-impact investing. Interview Sir Ronald Cohen. Mckinsey. Available at: https://www.mckinsey.com/industries/private-equity-and-principal-investors/ourinsights/the-changing-landscape-of-social-impact-investing.

3. Davies, G. B. (2015). The Value of Being Human: A Behavioural Framework for Impact-Investing and Philanthropy. Philanthropy Impact Magazine, 14, 15-18. Available at: https://www.philanthropyimpact.org/sites/default/files/user-uploads/pi_magazine_14_pgs_15-18.pdf.

4. French, Sh. (2017). Understanding ESG Investing. Answers to advisors' and investors' most pressing questions about ESG. Available at: https://www.etf.com/publications/etfr/understanding-esg-investing.

5. GIIN (2020). Annual Impact Investor Survey. Available at: https://thegiin.org/research/publication/impinvsurvey-2020.

6. GIIN (2020). The State of Impact Measurement and Management Practice. Second Edition Global Impact Investing Network January. Available at: https://thegiin.org/research/publication/imm-survey-second-edition.

7. Johnson, K., Lee H. (2013). Impact-Investing: A Framework for Decision Making. Cambridge Associates LLC. DOI: https://doi.org/10.1007/s11135-015-0245-6.

8. Niculescu M. (2017). Impact investment to close the SDG funding gap. UNDP material. Available at: https://www.undp.org/content/undp/en/home/blog/2017/7/13/What-kind-ofblender-do-we-need-tofinance-the-SDGs-.html/.

9. Payiatakis, D., Brooks P. (2018). Investor motivations for impact: A behavioural examination. Barclays, 35 p. Available at: https://www.barclays.co.uk/content/dam/documents/wealth-management/investments/impactinvesting-product/investor-motivations-for-impact.pdf.

10.Roadmap for the Future of Impact-Investing: Reshaping Financial Markets. Available at: https://thegiin.org/research/publication/giin-roadmap.

11.Wood, D., Thornley, B., Grace, K., Sullivant, S. (2011). Impact-Investing: A Framework for Policy Design and Analysis. Insight at Pacific Community Ventures and The Initiative for Responsible Investment at Harvard University, January 101 p. Available at: http://www.pacificcommunityventures.org/wpcontent/uploads/sites/6/2015/07/Impact Investing Policy Full Report.pdf.

12.Katalog diy kompaniy dlya borot'by z COVID-19 [Catalogue of companies' actions to fight against COVID-19. Available at: https://csr-ukraine.org/covid-19/as of 1.08.2020.

13.Monitoryng Derzhavnykh investytsiynykh proektiv za 2016 rik [Monitoring of State Investment Projects for 2016]. Ministry of Development of Economy, Commerce and Agriculture of Ukraine. Available at: https://www.me.gov.ua/Documents/List?lang=uk-UA\&id=40253ac5-2a8c-447d-857d$\underline{1 \mathrm{a} 34739 \mathrm{~d} 765 \mathrm{a} \& \text { tag }=\text { MonitoringStanuVikonanniaTaRealizatsiiDerzhavnikhInvestitsinikhProektiv. }}$

14.Tsili stalogo rozvytku Ukrayiny. Dobrovilny natsionalny oglyad [Goals of sustainable development of Ukraine. Voluntary national review]. Available at: https://mof.gov.ua/storage/files/.

15. Yatsenko, A. V. (2010). Formuvannya investytsiynoyi polityky zi strategichnykh pozytsiy rozvytku Ukrayiny [Formation of investment policy from the strategic standpoint of Ukraine's development]. Investment: practice and experience, 8, 12-17. Available at: http://www.investplan.com.ua/pdf/8 2010/5.pdf. 